\title{
Metastatisk prostatakreft bør følges i spesialisthelsetjenesten
}

KOMMENTAR

\section{ARNE STENRUD BERG}

E-post: arne.stenrud.berg@gmail.com Arne Stenrud Berg er overlege ved Onkologisk poliklinikk, Drammen sykehus. Oppgitte interessekonflikter: Forfatter har mottatt honorarer for foredrag, forfatteroppdrag og deltagelse på rådgivningsmøter fra Bayer, Astellas, Amgen og Novartis.

\section{TORGRIM TANDSTAD}

Torgrim Tandstad er overlege og forsker ved Kreftklinikken, St. Olavs Hospital. Ingen oppgitte interessekonflikter.

Takk for god artikkel om et viktig tema. Vi mener imidlertid at de som starter behandling mot metastatisk prostatakreft som hovedregel bør kontrolleres i spesialisthelsetjenesten, gjerne i samarbeid med fastlege i tilfeller der man oppnår god og langvarig effekt av den initiale behandlingen. Den medisinske behandlingen av metastatisk prostatakreft har endret seg mye de siste årene, og det kan ikke forventes at fastleger til enhver tid skal være oppdatert på et så spesialisert onkologisk fagområde. To helt nye randomiserte studier, som forfatterne naturligvis ikke har rukket å referere til, har vist overlevelsesgevinst ved å kombinere initial kastrasjon med abirateron $(1,2)$. Median varighet av kastrasjonsfølsom fase for de med negative prognostiske faktorer var bare syv måneder med kastrasjonsbehandling alene (1). Over halvparten døde innen tre år. Det er godt dokumentert at det å utsette optimal behandling ved asymptomatisk progrediering, gir prognosetap (3,4). Anbefalingen i artikkelen om oppfølging hos fastlegen med PSA-måling hver 3-6 måned, med referanse til gjennomsnittlig varighet av kastrasjonsfølsom fase på tre år, bygger opp under en utbredt og uheldig misoppfatning av at metastatisk prostatakreft er langsomt utviklende, og at pasientene derfor ikke trenger tett oppfølging. Pasienter med nydiagnostisert metastatisk prostatakreft bør som hovedprinsipp alltid vurderes av onkolog kort tid (dvs. innen to måneder) etter at kastrasjonsbehandling er startet, for å unngå prognosetap.

\section{LITTERATUR:}

1. LATITUDE Investigators. Abiraterone plus prednisone in metastatic, castration-sensitive prostate cancer. N Engl J Med 2017; 376: Epub ahead of print. [PubMed][CrossRef]

2. STAMPEDE Investigators. Abiraterone for prostate cancer not previously treated with hormone therapy. N Engl J Med 2017; 376: Epub ahead of print. [PubMed][CrossRef]

3. COU-AA-302 Investigators. Abiraterone acetate plus prednisone versus placebo plus prednisone in 
chemotherapy-naive men with metastatic castration-resistant prostate cancer (COU-AA-302): final overall survival analysis of a randomised, double-blind, placebo-controlled phase 3 study. Lancet Oncol 2015; 16: 152 - 6o. [PubMed][CrossRef]

4. Beer TM, Armstrong AJ, Rathkopf D et al. Enzalutamide in men with chemotherapy-naive metastatic castration-resistant prostate cancer: Extended analysis of the phase 3 PREVAIL study. Eur Urol 2017; 71: 151 - 4. [PubMed][CrossRef]

Publisert: 21. august 2017. Tidsskr Nor Legeforen. DOI: 10.4045/tidsskr.17.0578

(C) Tidsskrift for Den norske legeforening 2020. Lastet ned fra tidsskriftet.no 